\title{
Evaluation of Secondary Coolant Control Design Alternatives and Their Effects on Heat Removal
}

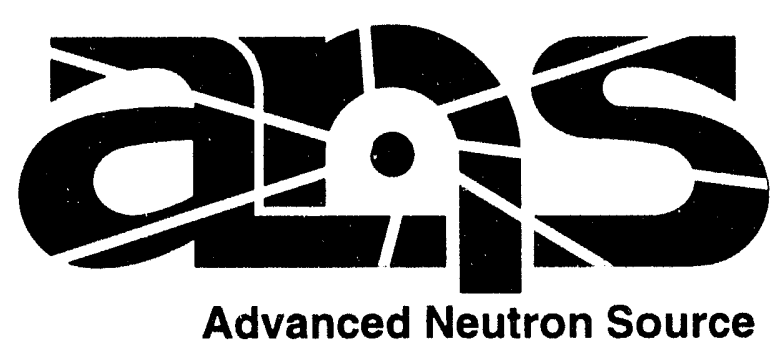


This report has been reproduced directly from the beet available copy.

Avalable to DOE and DOE contractors from the Office of Scientfic and Tecturt cal information, P.O. Box 62, Oak Ridge, TN 37831; prices available from (615) 576-8401, FTS 626-8401.

Avallable to the public from the National Technical Information Service, U.S. Departivient of Commerce, 5285 Port Royal Rd., Sprinofield, VA 22161.

This report was prepared as an account of work sponsored by an agency of the United States Government. Neither the United States Government nor any agency thereof, nor any of their employees, makes any warranty, express or implied, or assumes any legal liability or responsibility for the accuracy, com pleteness, or usetulness of any information, apparatus, product, or process disclosed, or represents that its use would not intringe privately owned rights. Reference herein to any specific commercial product, process, or service by trade name, trademark, manufacturer, or otherwise, does not necessarily constitute or imply its endorsement, recommendation, or favoring by the United States Government or any agency thereof. The views and opinions of authors expreseed herein do not necessarily state or reflect those of the United States Government or any agency thereof. 
ORNLTM-12649

\title{
EVALUATION OF SECONDARY COOLANT CONTROL DESIGN ALTERNATIVES AND THEIR EFFECTS ON HEAT REMOVAL PERFORMANCE
}

\author{
Mohammed Ibn Khayat \\ John Anderson \\ Ron Battle \\ Jose March-Leuba
}

March 1994

"This research was supported in part by an appointment to the Oak Ricige National Laboratory and the Oak Ridge Institute for Science and Education.

\author{
Prepared by \\ OAK RIDGE NATIONAL LABORATORY \\ managed by \\ MARTIN MARIETTA ENERGY SYSTEMS, INC. \\ for the \\ U. S. DEPARTMFNT of ENERGY \\ under contract DE-AC05-84OR21400
}

AROMIBUTION OF THIS DOCUMENT IS URLIMITE: 


\section{CONTENTS}

LIST OF FIGURES $\ldots \ldots \ldots \ldots \ldots \ldots \ldots \ldots \ldots \ldots \ldots \ldots \ldots \ldots \ldots$

ABSTRACT $\ldots \ldots \ldots \ldots \ldots \ldots \ldots \ldots \ldots \ldots \ldots \ldots \ldots \ldots \ldots \ldots \ldots \ldots \ldots \ldots$

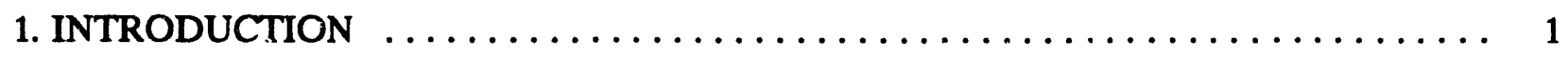

2. DESIGN DESCRIPTION OF PROPOSED CONTROLLERS $\ldots \ldots \ldots \ldots \ldots \ldots \ldots$ 2.1 OPTION 1: VARIABLE-SPEED PUMP AND VARIABLE-SPEED FANS $\ldots . .3$ 2.2 OPTION 2: SINGLE-SPEED PUMP WITH VARIABLE-SPEED FANS $\ldots \ldots .5$ 2.3 OPTION 3: SECONDARY OUTLE' $\Gamma$ TEMPERATURE CONTROL . . . . . . . 5

3. DYNAMIC MODEL USED FOR SIMULATIONS AND CONTROLLER DESIGN . . . 7

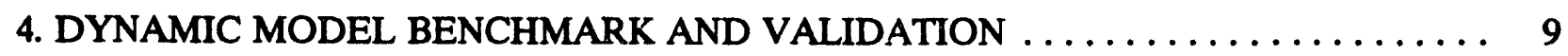

5. RESULTS $\ldots \ldots \ldots \ldots \ldots \ldots \ldots \ldots \ldots \ldots \ldots \ldots \ldots \ldots \ldots \ldots \ldots \ldots$

5.1 OPTION 1: VARIABLE-SPEED PUMP AND VARIABLE-SPEED FANS $\ldots \ldots 11$

5.2 OPTION 2: SINGLE-SPEED PUMP AND VARIABLE-SPEED FANS $\ldots \ldots \ldots 11$

5.3 OPTION 3: SECONDARY OUTLET TEMPERATURE CONTROL . . . . . . . 12

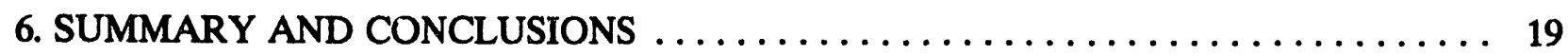




\section{LIST OF FIGURES}

Fig. 1. Core-outlet temperature response-sensitivity to integral controller gain

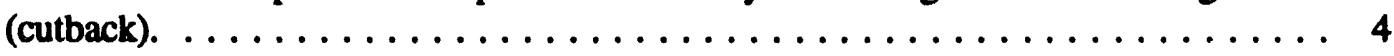

Fig. 2. Core-inlet temperature response-sensitivity to integral controller gain (setback). . . . . . . . . . . . . . . . . . . . . . . . . . 4

Fig. 3. PRSDYN code block diagram for the Advanced Neutron Source reactor cooling circuit. ................................. 8

Fig. 4. PRSDYN benchmark - calculated core-outlet temperature vs High Flux Isotope

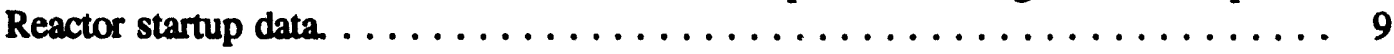

Fig. 5. PRSDYN benchmark-calculated core-inlet temperature vs High Flux Isotope Reactor startup data . . . . . . . . . . . . . . . . . . . . . . 10

Fig. 6.

Fig. 7. Core-inlet temperature for Option $1 . \ldots \ldots \ldots \ldots \ldots \ldots \ldots \ldots \ldots \ldots \ldots$

Fig. 8. Secondary mass flow rate for Option $1 . \ldots \ldots \ldots \ldots \ldots \ldots \ldots \ldots \ldots \ldots$

Fig. 9. Cooling tower heat load for Option $1 . \ldots \ldots \ldots \ldots \ldots \ldots \ldots \ldots \ldots$

Fig. 10.

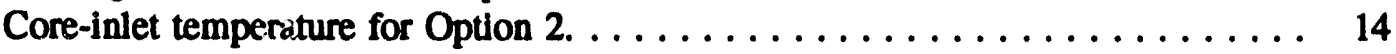

Fig. 11. Cooling tower heat load for Option $2 . \ldots \ldots \ldots \ldots \ldots \ldots \ldots \ldots \ldots$

Fig. 12. Secondary hot-leg temperature for Option $3 . \ldots \ldots \ldots \ldots \ldots \ldots \ldots \ldots$

Fig. 13.

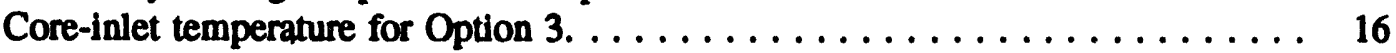

Fig. 14. Secondary flow rate for Option $3 . \ldots \ldots \ldots \ldots \ldots \ldots \ldots \ldots \ldots \ldots \ldots \ldots \ldots$

Fig. 15. Cooling tower heat load for Option 3.

Core-inlet and secondary hot-leg temperature for Option 3 following a power reduction to $40 \%$ when fan speed is not properly selected. . . . . . . . . . 17

Fig. 16. Secondary flow rate and cooling tower heat load for Option 3 following a power reduction to $40 \%$ when fans speed is not properly selected. 


\begin{abstract}
This report documents a series of calculations that evaluate the performance of the coreinlet temperature controller under different transient conditions and design options. The present analyses show that the core-inlet temperature can be controlled at $\sim 45^{\circ} \mathrm{C}$ under all transient conditions analyzed using the controller design described in the conceptual design report, which includes variable-speed secondary coolant pumps and variable-speed cooling tower fans. This study also shows that a constant-speed secondary pump would be sufficient to maintain core-inlet temperature $<45^{\circ} \mathrm{C}$ if this temperature is allowed to drop below the set point during some demanding transients, such as normal startup. The use of secondary loop hot coolant to warm the reactor building was also evaluated; however, optimization of the secondary hot-leg temperature can only be achieved by trading off control of the primary side core-inlet temperature.
\end{abstract}




\section{INTRODUCTION}

The Advanced Neutron Source (ANS) conceptual design has a complete and independent secondary coolant loop for each of the four independent primary coolant loops. One of the control objectives is to maintain the cold-leg temperature of each of the three active loops $545^{\circ} \mathrm{C}$ during normal operation (the scram temperature set point is $50^{\circ} \mathrm{C}$ ) by controlling either the variable-speed secondary pumps, the cooling tower fans, or both. The conceptual design calls for reactor-inlet temperature control to $45 \pm 1^{\circ} \mathrm{C}$ steady state and $45 \pm 3^{\circ} \mathrm{C}$ during transients (overshoot). The reactorinlet temperature controller design is complicated by the long time constants of the cooling circuits, the nonlinearity of the system, and the environmental conditions of the cooling tower.

These restrictions make controller design difficult, especially when regulation of the core-inlet temperature for the two extremes of startup and shutdown and fast and slow transients is required. Unlike the High Flux Isotope Reactor (HFIR), which controls part of the flow (20\%) automatically, it is expected that the ANS reactor (ANSR) will use fully automatic control for the secondary flow by adjusting the secondary pump speed. Some relevant requirements that affect the design of the secondary pump speed controller are listed below.

1. Reactor-inlet temperature must always be $<50^{\circ} \mathrm{C}$ with nominal control $545^{\circ} \mathrm{C}$.

2. The controller must accommodate a fast reactor startup (10\%-100\%) in $\leq 2 \mathrm{~min}$. This fast power ascension is required to overcome xenon bulldup during recovery from scram.

3. A minimum pump speed of $45 \%$ of nominal full speed is required to overcome the static head caused by the cooling tower elevation and keep the secondary flow circulating through the cooling tower.

4. The controller must be reliable, simple, and within acceptable cost conditions.

Since ANSR has three entirely separate cold legs, it is necessary to keep all three loops within $\sim 1^{\circ} \mathrm{C}$ of each other. To date, the lower limit of the reactor-inlet temperature has not been determined. One proposal is to allow the reactor-inlet temperature to remain significantly $<45^{\circ} \mathrm{C}$ when excess cooling capacity is available, giving the controller another degree of freedom. A variable core-inlet temperature margin relaxes controller performance requirements and augments the simplicity and reliability. Other proposed designs will be discussed in the subsequent sections.

The objective of this report is to evaluate methods of controlling reactor-inlet temperature or heat removal and recommend the best approach by considering performance, reliability, and cost. To accomplish this goal, three control schemes under various plant and weather conditions are evaluated. 


\section{DESIGN DESCRIPTION OF PROPOSED CONTROLLERS}

There are several possible ways to control the core-inlet temperature. Three designs are discussed in this report. The first design uses a proportional controller to regulate the core-inlet temperature by controlling secondary pump speed and variable-speed fans to control off-tower temperature at $-30^{\circ} \mathrm{C}$. The second design uses single-speed secondary pumps and variable-speed tower fans. The third design uses variable-speed secondary pumps to regulate the secondary hot-leg outlet temperature to $-45^{\circ} \mathrm{C}$ and variable-speed tower fans to regulate the off-tower temperature at $30^{\circ} \mathrm{C}$.

\subsection{OPTION 1: VARIABLE-SPEED PUMP AND VARIABLE-SPEED FANS}

The control scheme using a variable-speed pump and variable-speed fans is the ANS baseline as described in the conceptual design report (CDR). In this scheme, both the secondary coolant pump and the cooling tower fans have variable-speed motors. The objective of this design option is to maintain tight control of the reactor-inlet temperature during steady-state operation at nominal conditions (the desired accuracy is $45 \pm 1^{\circ} \mathrm{C}$ ). During transients and off-normal operating conditions, the temperature is allowed to drift lower (1.e., the controller is designed to overcool the primary system). The controller in this option determines the normalized secondary coolant pump speed, using a standard proportional controller, that can be described by the following equation:

$$
n_{z}=k_{p} \times\left(T-T_{m}\right) \text {, }
$$

where

$$
\begin{aligned}
& n_{s}=\text { normalized secondary coolant pump speed }(\%) \\
& k_{p}=\text { proportional controller gain }(\%) \\
& T=\text { core-inlet temperature as sensed by the cold-leg temperature detector }\left({ }^{\circ} \mathrm{C}\right), \\
& T_{m}=\text { the temperature set point }\left(\mathrm{CDR} \text { value is } 45^{\circ} \mathrm{C}\right) .
\end{aligned}
$$

The controlled pump speed, $n_{s}$, is not allowed to be greater than the maximum pump speed, $n_{t-\max }$ (the CDR value is $120 \%$ ), or the minimum pump speed, $n_{s-\min }$ (the CDR value is $\sim 45 \%$ ), required to overcome the cooling tower elevation and maintain positive secondary coolant flow. It is important to note that the simulations in this report indicate that an integral controller component cannot be used for this purpose because it would lead to significant temperature overshoots during fast (few seconds) power ascension. Figure 1 shows the response of the system for a power cutback from 100 to $40 \%$ before the fast power setback to $100 \%$ shown in Fig. 2. With this option, the controlled temperature is a function of power level (actually of the required secondary flow) and may become significantly $<45^{\circ} \mathrm{C}$ by allowing the controller to have a steady-state error. The off-tower secondary coolant temperature is controlled in this design option by adjusting the speed of the cooling tower fans. All 


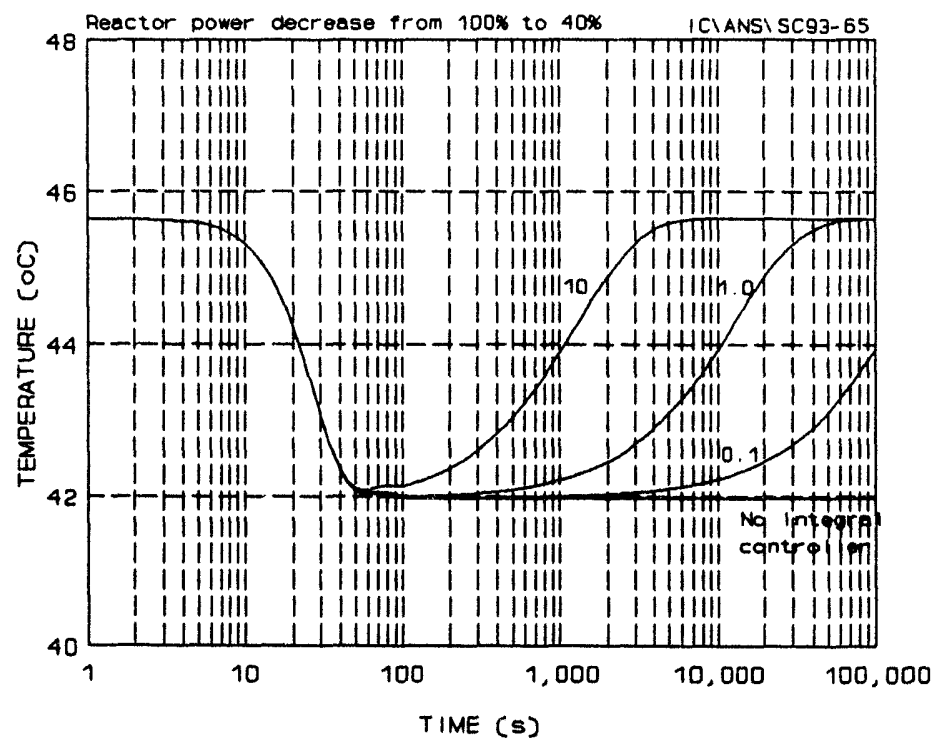

Fig. 1. Core-inlet temperature responso-sensitivity to integral controller gain (cutback).

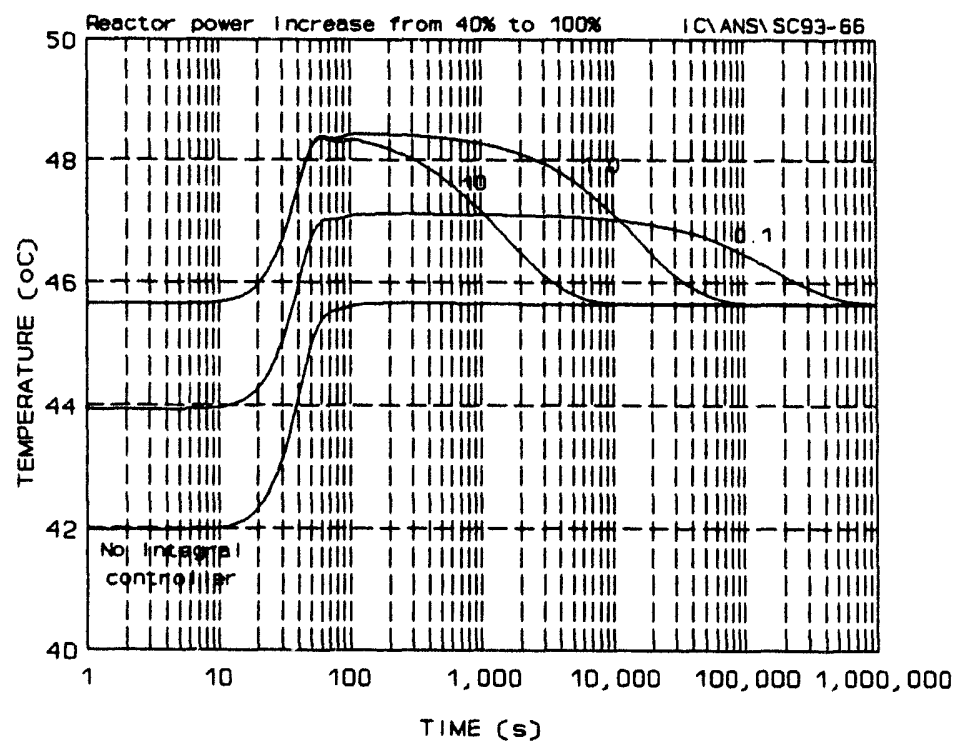

Fig. 2. Core-inlet temperature response-sensitivity to integral controller gain (setback). 
fans are operated at the same speed, and all cooling towers are active at all operating powers. The normalized fan speed, $n_{f}$, for this option is controlled using a standard proportional-integral (PI) controller, which can be described by the following equation:

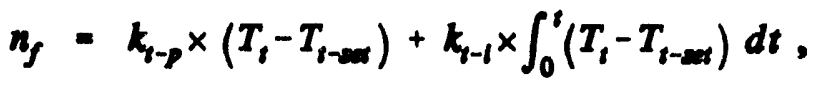

where

$$
\begin{aligned}
& n_{f}=\text { controlled fan speed }(\%), \\
& k_{t-p}=\text { proportional controller gain }\left({ }^{\circ} \mathrm{C}^{-1}\right) \text {, } \\
& T_{t}=\text { off-tower temperature as sensed by the off-tower coolant temperature detector }\left({ }^{\circ} \mathrm{C}\right), \\
& \left.T_{t-\text { ese }}=\text { off-tower temperature set point (the } \mathrm{CDR} \text { value is } 30^{\circ} \mathrm{C}\right), \\
& k_{t-l}=\text { integral controller gain }\left({ }^{\circ} \mathrm{C}^{-1} \cdot \mathrm{s}^{-1}\right) .
\end{aligned}
$$

The controlled fan speed, $n_{f}$, is not allowed to be greater than the maximum fan speed, $n_{f-\max }$ (CDR value is $100 \%$ ).

\subsection{OPTION 2: SINGLE-SPEED PUMP WITH VARIABLE-SPEED FANS}

The objective of this control scheme is to increase the reliability and reduce the capital cost of the secondary cooling system by using a single-speed coolant pump (as opposed to a variable-speed pump). To accomplish this objective, the reactor-core-inlet temperature must be allowed to operate at significantly $<45^{\circ} \mathrm{C}$ because the excess cooling capacity (100\% pump speed) results in lower inlet temperature for non-nominal operating conditions. Transient operations (e.g., startup) under this option will result in large temperature variations, but these operations should not cause a scram because the single-speed pump is designed to provide sufficient cooling for all expected operating conditions. If there is a lower limit on the core-inlet temperature, then this option may be eliminated.

For this design option, the off-tower temperature is maintained constant by controlling the speed of the cooling tower fans. This control is implemented as a PI controller similar to the one described in Sect. 2.1. The core-inlet temperature is no longer directly controllable. This lack of control could be a problem with the current conceptual design because each of the seperate cold legs of the primary needs to be maintained at essentially the same temperature.

\subsection{OPTION 3: SECONDARY OUTLET TEMPERATURE CONTROL}

The objective of this design option is to maintain the secondary heat exchanger outlet coolant temperature as high as possible for use by the heating, ventilation, and air-conditioning (HVAC) system and allow the primary coolant temperature to vary. The secondary temperature must be $244^{\circ} \mathrm{C}$ for this option to be feasible. For this study, the selected secondary hot-leg temperature is $45^{\circ} \mathrm{C}$. Implementing this option requires the control of secondary heat exchanger outlet temperatures at $45^{\circ} \mathrm{C}$ using variable speed secondary pumps and a PI controller. The off-tower temperature is regulated at $30^{\circ} \mathrm{C}$ using variable-speed fans and the PI controller described in Sect. 2.1. The core-inlet temperature is no longer directly controllable. This lack of control could be a problem with the current conceptual 
design because each of the separate cold legs of the primary needs to be maintained at essentially the same temperature. 


\section{DYNAMIC MODEL USED FOR SIMULATIONS AND CONTROLLER DESIGN}

PRSDYN is a dynamic model developed for the purpose of simulating the thermalhydraulic and control response of the ANS primary and secondary cooling systems for both steady-state and transient scenarios, such as startup. It models the flow rate changes, pressure variations, temperature behavior, and heat exchange between the primary and the secondary cooling circuits. Figure 3 shows the ANS PRSDYN dynamic model block diagram. Because of the low pressure at the secondary side of the heat exchangers, the flow-pressure dynamics are limited by the pump transient response. Consequently, any flow or pressure changes within the secondary cooling circuit components are derived from the pump flow and pressure changes. The mode 1 is used to evaluate secondary cooling system design alternatives, and consequently, changes in the actual design configuration are to be expected.

The PRSDYN model has three independent loops, each of which transfers heat from its primary side to its secondary side. For the transients examined, the loops were operated in concert with identical conditions as if only one loop existed. The model is written in modular form (as shown in Fig. 3) and includes the following modules: pipe, pump, basin, cooling tower ventilation, valves, junction, header, core and heat exchangers. The model runs on a personal computer (PC) and is coded in Advanced Continuous Simulation Language (ACSL).

In order to simulate effectively the control of the ANSR inlet temperature, experimental data suggested by Gilbert/Commonwealth, Inc., for the proposed heat exchangers, cooling tower fans, and ANS CDR parameters were used within the model to approximate the conceptual design as accurately as possible. 


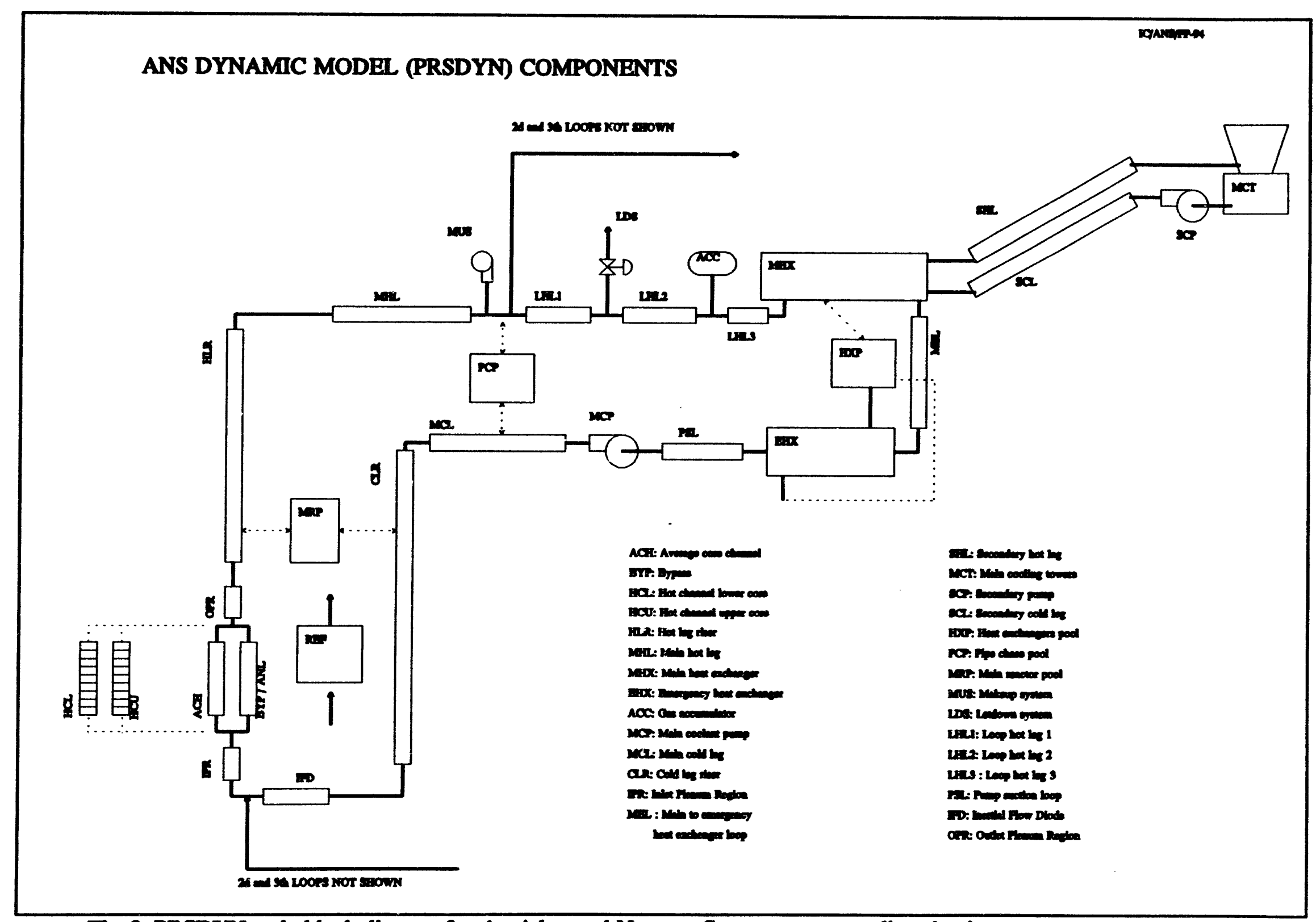

Fig. 3. PRSDYN code block diagram for the Advanced Neutron Source reactor cooling circuit. 


\section{DYNAMIC MODEL BENCHMARK AND VALIDATION}

The PRSDYN dynamic model has been validated against calculations and experimental results. The mathematics of the model, which involves mass momentum and energy conservation, were reviewed, and hand calculations were performed to confirm that the steady-state conditions were correct. In addition to steady state, several transients were evaluated, and the results of the simulations were judged satisfactory. These transients included startup, loss of secondary pumping power, loss of primary pumping power, secondary side natural circulation, and loss of cooling tower ventilation.

To complete the validation of the PRSDYN dynamic model, a benchmark against experimental results was performed and hand calculations were used. For this purpose, a typical power escalation profile and flow shape from a recent HFIR startup were used. The results with the PRSDYN model, adapted to HFIR calculations, were very close to the experimental results. Figures 4 and 5 show reactor-core-outlet and inlet temperatures, respectively, for this HFIR startup transient.

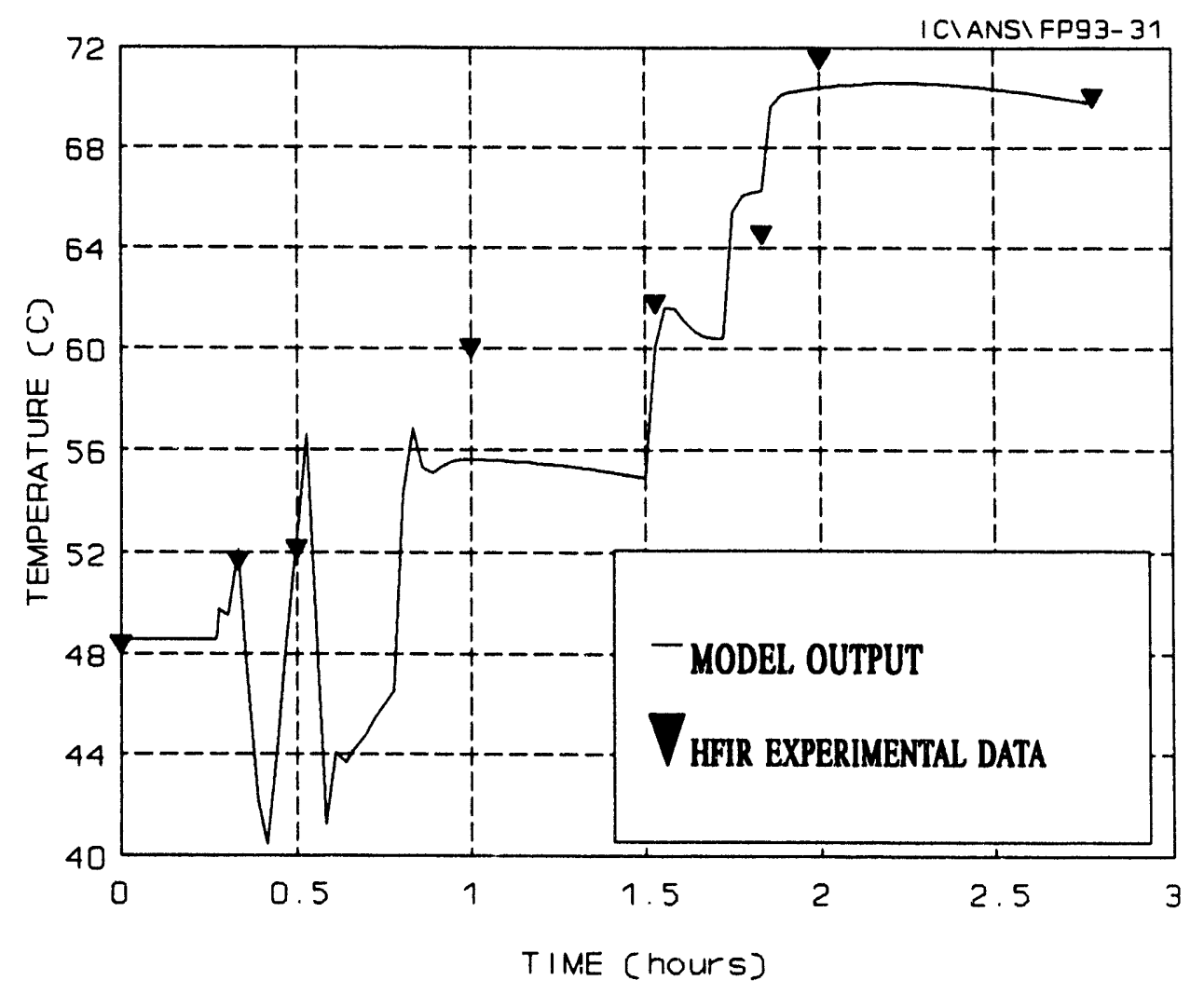

Fig. 4. PRSDYN ben-hmark-calculated core-outlet temperature vs High Flux Isotope Reactor startup data. 


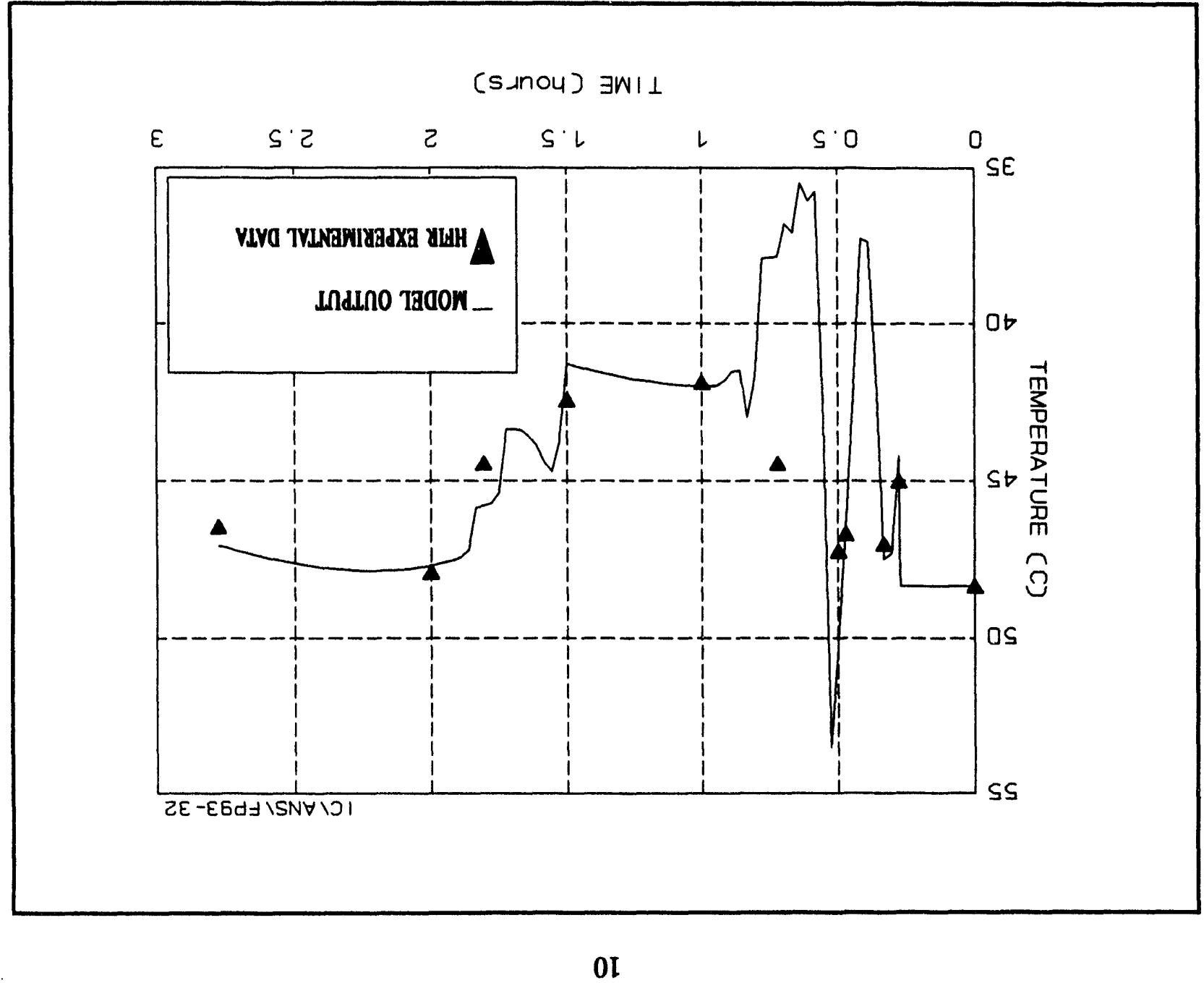




\section{RESULTS}

Tests have been performed to evaluate the response of the ANSR to different transient conditions. The control parameters used for these evaluations are summarized in Table 1 . The four transients investigated were:

1. fast restart from decay heat levels (before xenon buildup following shutdown);

2. setback to $40 \%$ power for up to $30 \mathrm{~min}$, then reseting the power to $100 \%$;

3. cold startup (fresh reactor) with hot basin; and

4. cold startup (fresh reactor) with cold basin.

These four transients are designated as cases 1, 2, 3 and 4 on Figs. 6-14.

Table 1. Control parameters used for the evaluations

\begin{tabular}{lll}
\hline Parameters & $\begin{array}{l}\text { Secondary coolant pump } \\
\text { speed } \mathrm{PI}^{a} \text { control constants }\end{array}$ & $\begin{array}{l}\text { Cooling tower fans speed PI } \\
\text { control constant }\end{array}$ \\
\hline Proportional gain & $\mathrm{K}_{\mathrm{p}}=12.5 \% \bullet{ }^{\circ} \mathrm{C}^{-1}$ & $\mathrm{~K}_{\mathrm{f}-\mathrm{p}}=65 \% \bullet{ }^{\circ} \mathrm{C}^{-1}$ \\
Integral gain & $\mathrm{N} / \mathrm{A}^{b}$ & $\mathrm{~K}_{\mathrm{f}-\mathrm{i}}=3.5 \% \bullet{ }^{\circ} \mathrm{C}^{-1} \bullet \mathrm{s}^{-1}$ \\
\hline${ }^{4} \mathrm{PI}=$ proportional-integral. & \\
${ }^{b} \mathrm{~N} / \mathrm{A}=$ not applicable. &
\end{tabular}

\subsection{OPTION 1: VARIABLE-SPEED PUMP AND VARIABLE-SPEED FANS}

Figures 6, 7, and 8 are related to Option 1-the fully controlled core-inlet temperature using variable-speed secondary pump and cooling tower fans. Figure 6 shows the core-inlet temperature for the four simulated cases. For all four cases, the temperature stabilized at $-45^{\circ} \mathrm{C}$, and no overshoot was detected. Figure 7 shows one loop secondary pump flow rate. Figure 8 shows the cooling tower heat removal performance extrapolated from the fan speeds. Depending on the weather conditions, the heat removal changes dramatically with air temperature. A fan running at $100 \%$ speed in summer removes less heat than the same fans running at $75 \%$ in winter.

\subsection{OPTION 2: SINGLE-SPEED PUMP AND VARIABLESPPEED FANS}

Figures 9 and 10 show the performance of the second proposed design, Option 2-singlespeed pumps with the cooling tower fans controlling the off-tower temperature at $\sim 30^{\circ} \mathrm{C}$. Figure 9 shows core-inlet temperature response to the four simulated cases. No overshoots were detected, and the core-inlet temperature reached $45^{\circ} \mathrm{C}$ in $200 \mathrm{~s}$, which is the main heat exchanger heat transfer time constant. This relatively fast response results from the fact that the basin temperature was kept nearly constant at $30^{\circ} \mathrm{C}$. The basin temperature was most likely maintained because the tower fans were controlled only by a proportional controller. An integral controller was tried and caused instability, and an derivative controller will not be efficient in this case because of the slow process of heat transfer between the primary side and the secondary side. 
Figure 10 shows the corresponding heat removal by the tower fans for each of the performed cases. Unless the basin temperature of each secondary loop is kept at the same temperature, this scheme may lead to undesirable situation such as different cold-leg temperatures.

\subsection{OPTION 3: SECONDARY OUTLET TEMPERATURE CONTROL}

Figures 11, 12, 13, and 14 are related to the third proposed design that is associated with the control of the secondary hot-leg temperature at $545^{\circ} \mathrm{C}$ and the regulation of the off-tower temperature at $30^{\circ} \mathrm{C}$. Figure 11 shows the secondary hot-leg temperature always kept at $545^{\circ} \mathrm{C}$. Controller gains were chosen experimentally for optimum performance with minimum overshoot. Figure 12 shows the corresponding core-inlet temperature always kept $-45^{\circ} \mathrm{C}$. Figure 13 shows the secondary pump flow rate extrapolated from the controlled pump speed. Figure 14 shows the cooling tower heat removal demand extrapolated from the fans speed. This scheme may lead to undesirable conditions if appropriate measures are not taken such as keeping the minimum heat removed by the fans at a high level (For Option 3, the fans were started at a speed equivalent to maximum heat removal $=110$ MW). The fact that the core-inlet temperature is no longer directly controllable is also an obstacle toward keeping the three independent cold legs at the same temperature. Figure 15 shows the core inlet temperature which went above the scram set point $\left(50^{\circ} \mathrm{C}\right)$ and the secondary hot leg temperature, for a power setback to $40 \%$, when the fans were not operating at the required speed. 


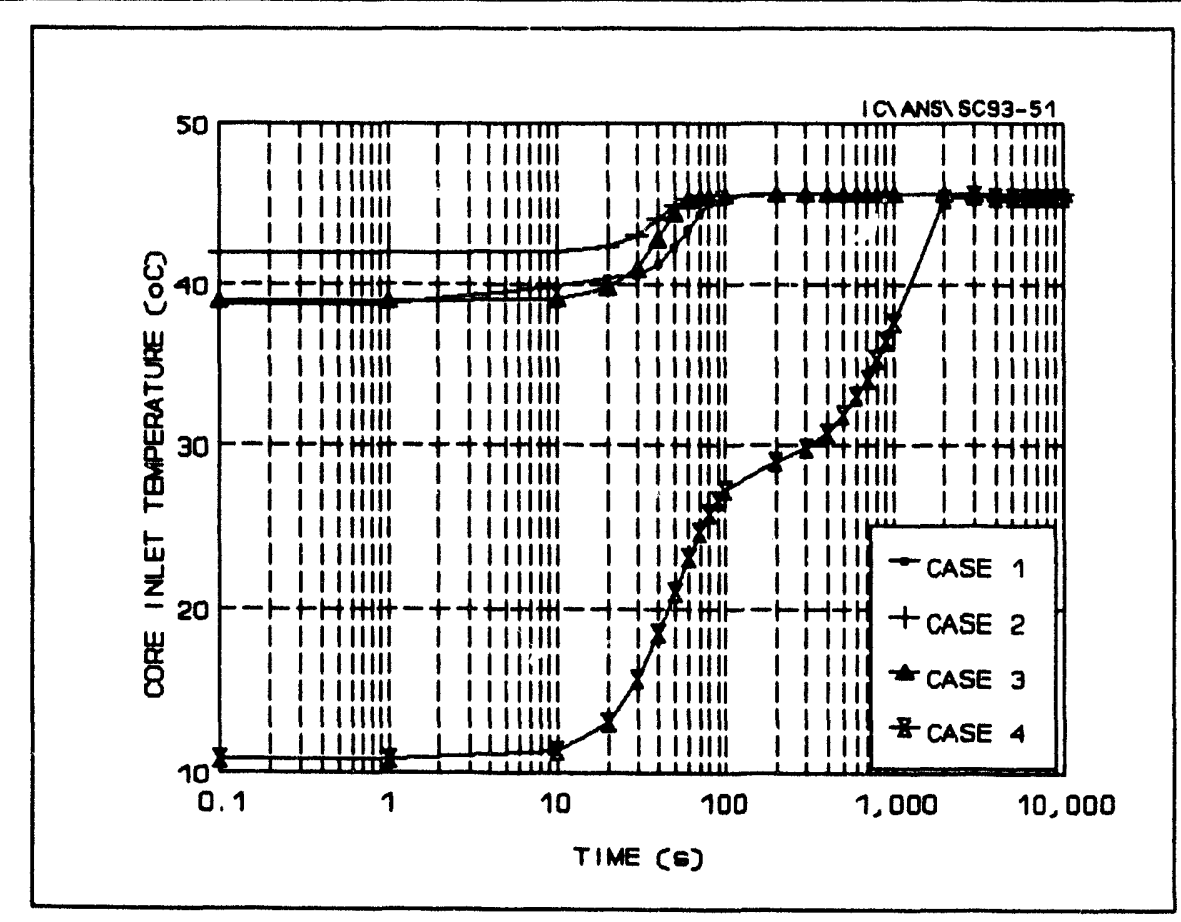

Fig. 6. Core-inlet temperature for Option 1.

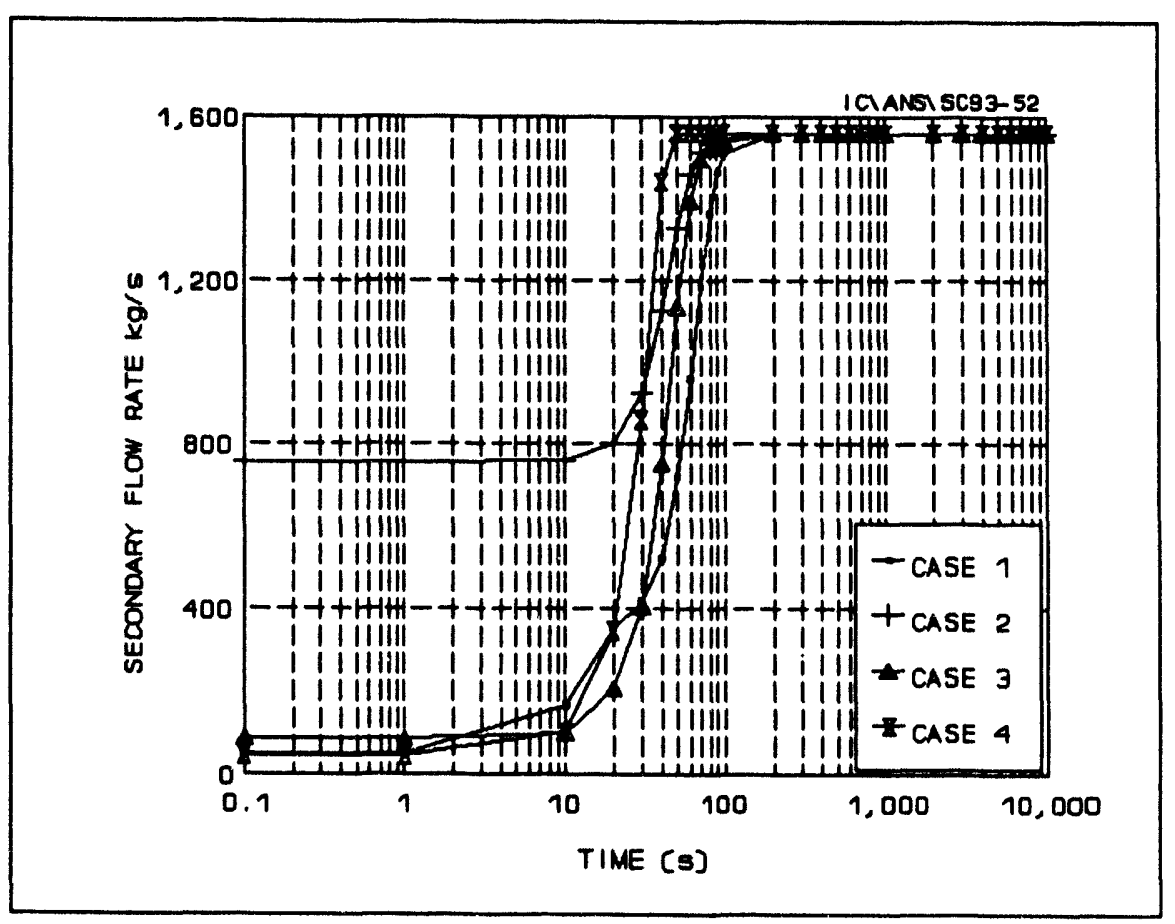

Fig. 7. Secondary mass flow rate for Option 1. 

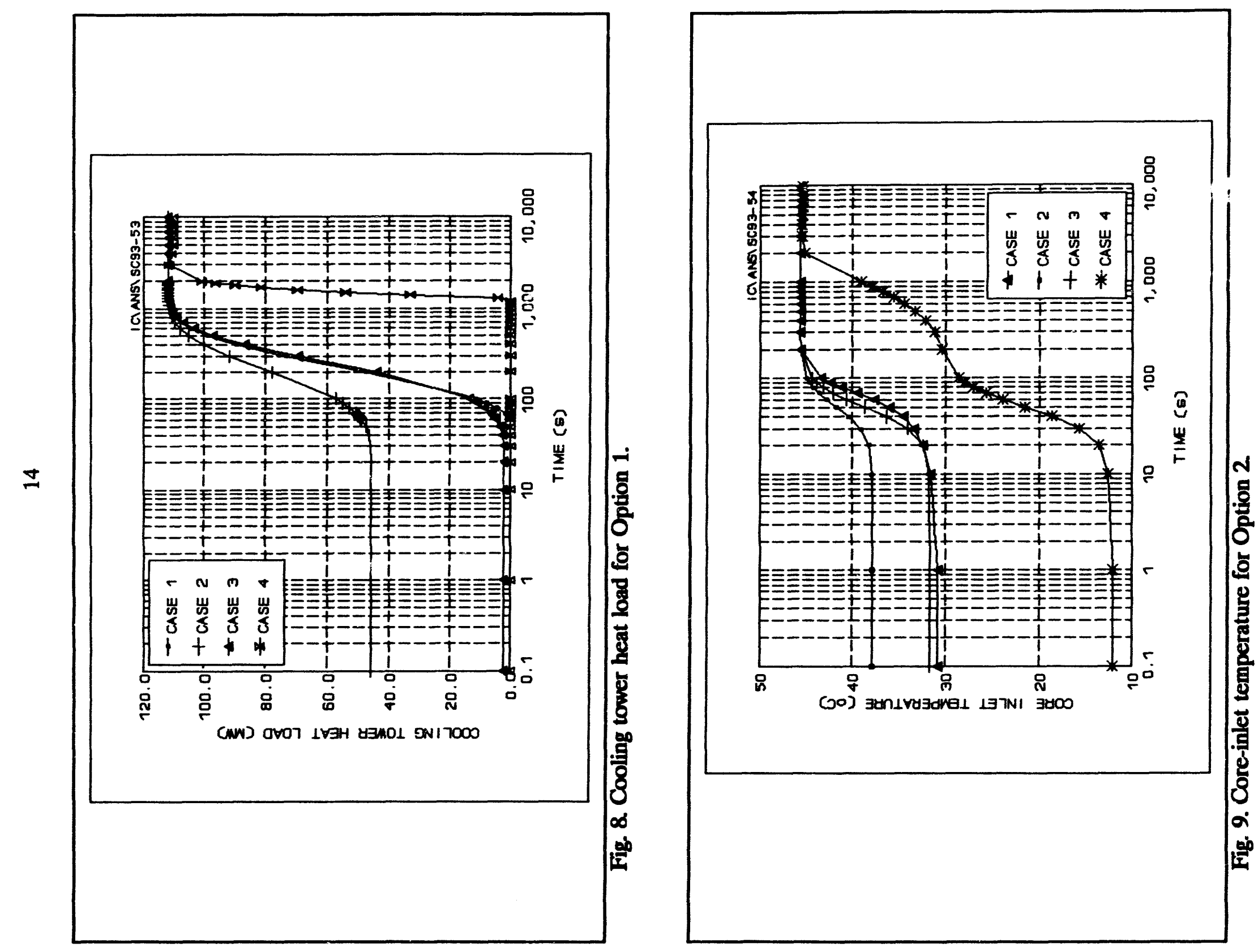


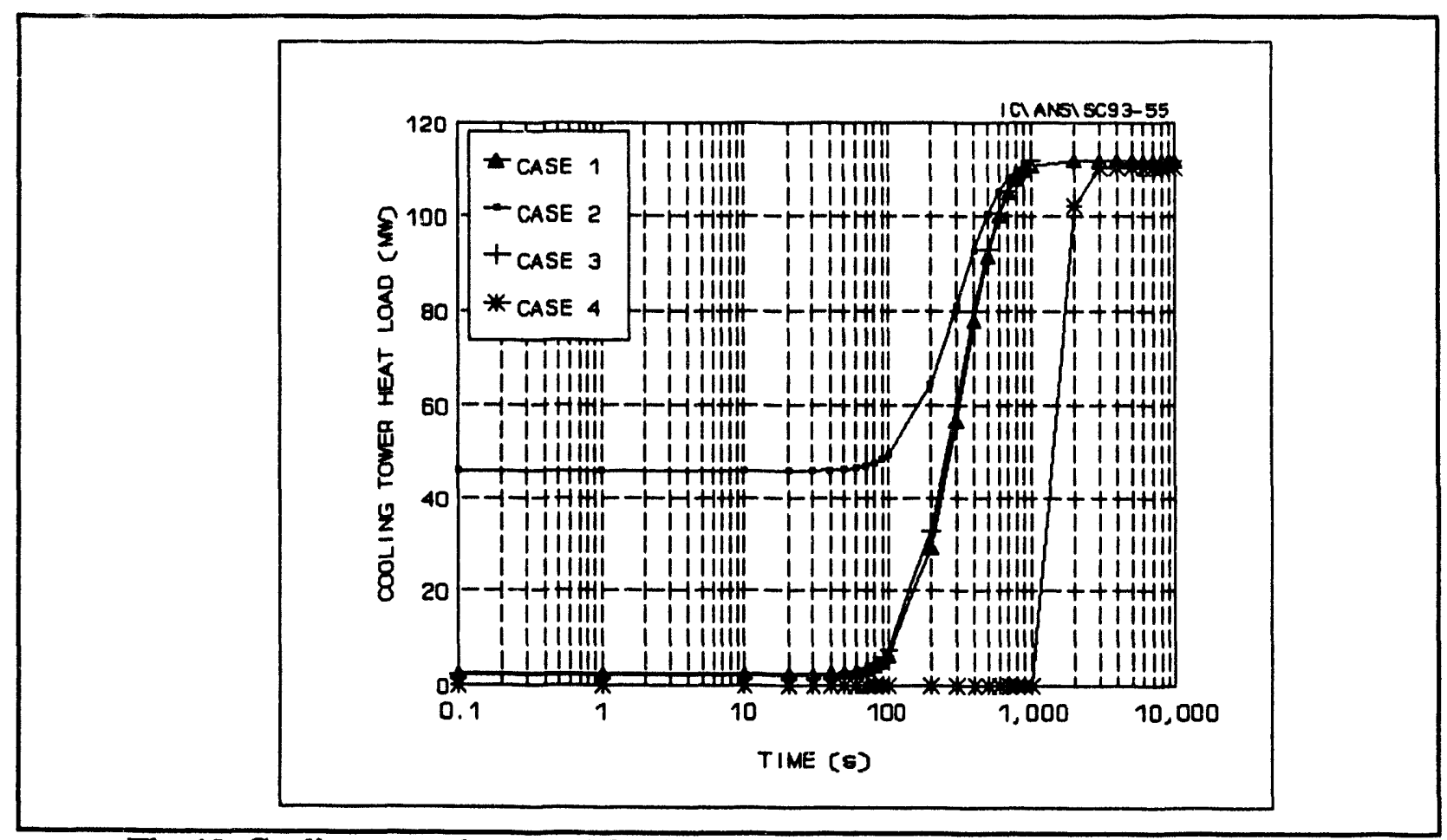

Fig. 10. Cooling tower heat load for Option 2

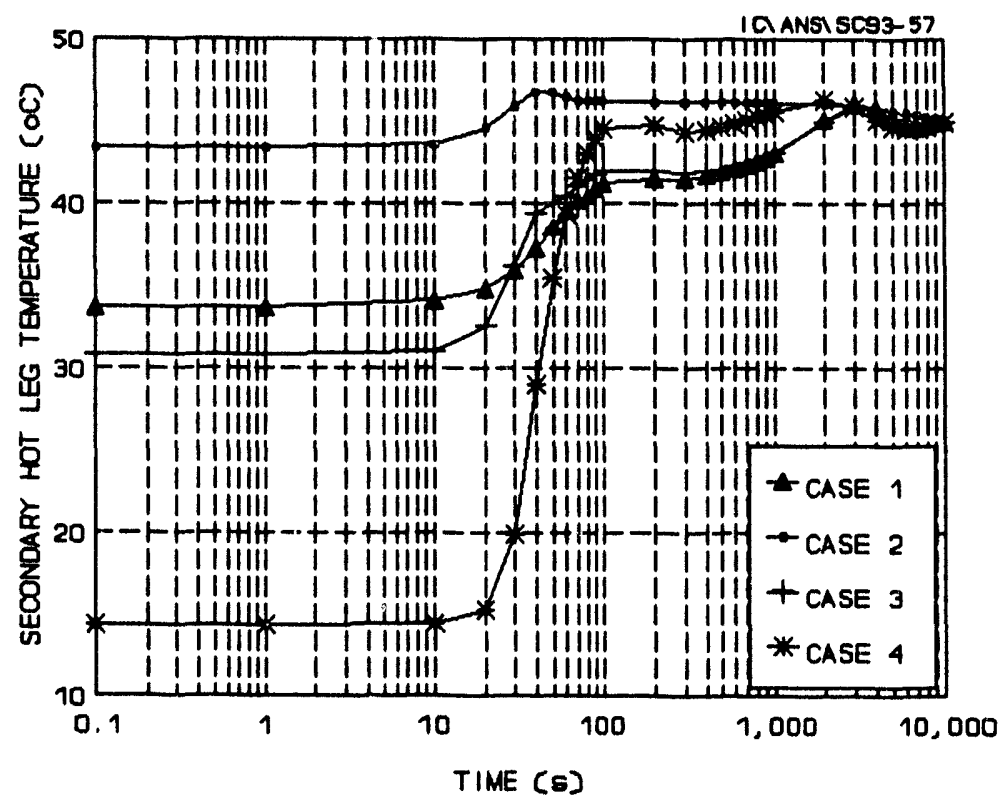

Fig. 11. Secondary hot-leg temperature for Option 3. 


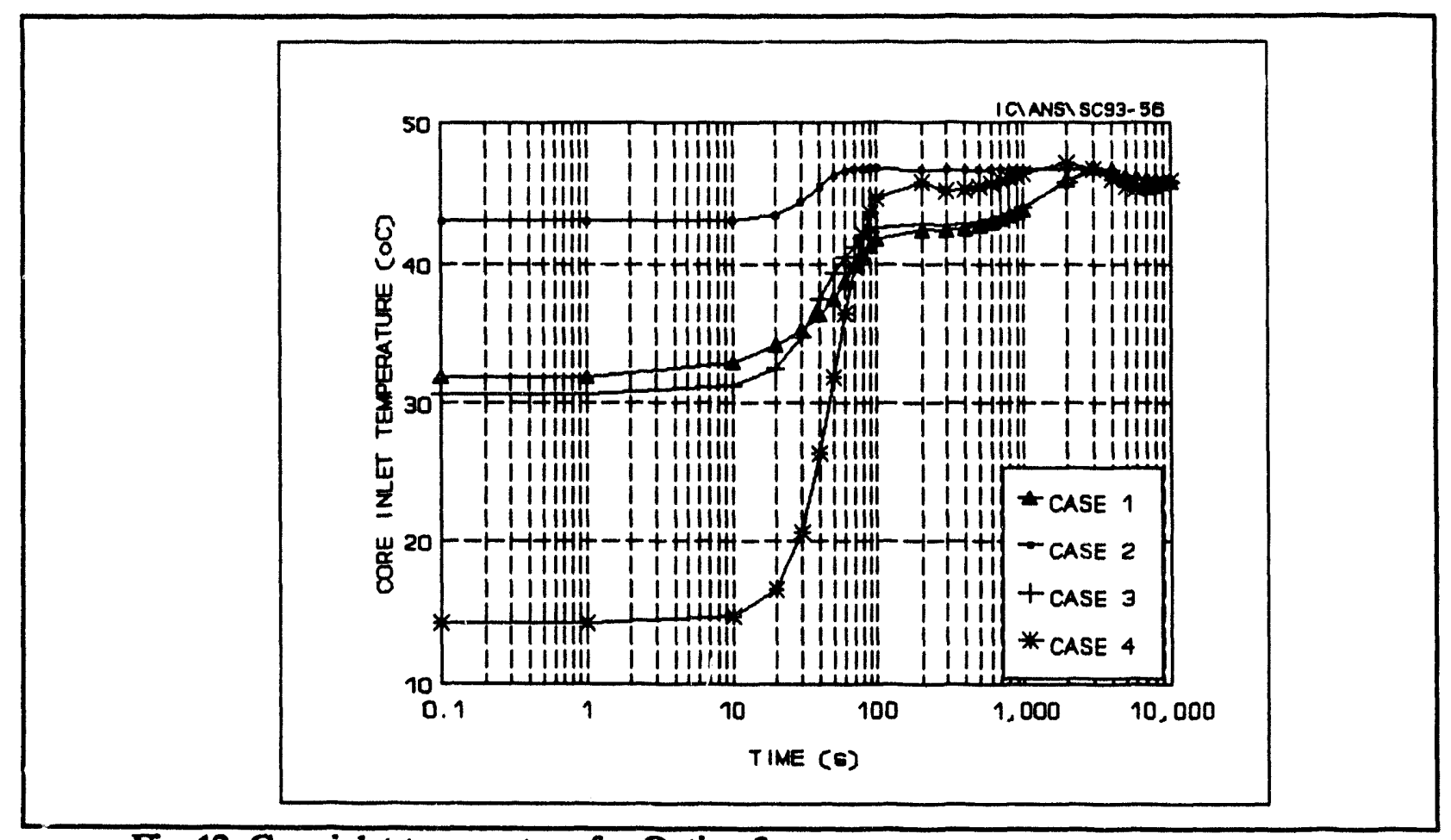

Fig. 12 Core-inlet temperature for Option 3.

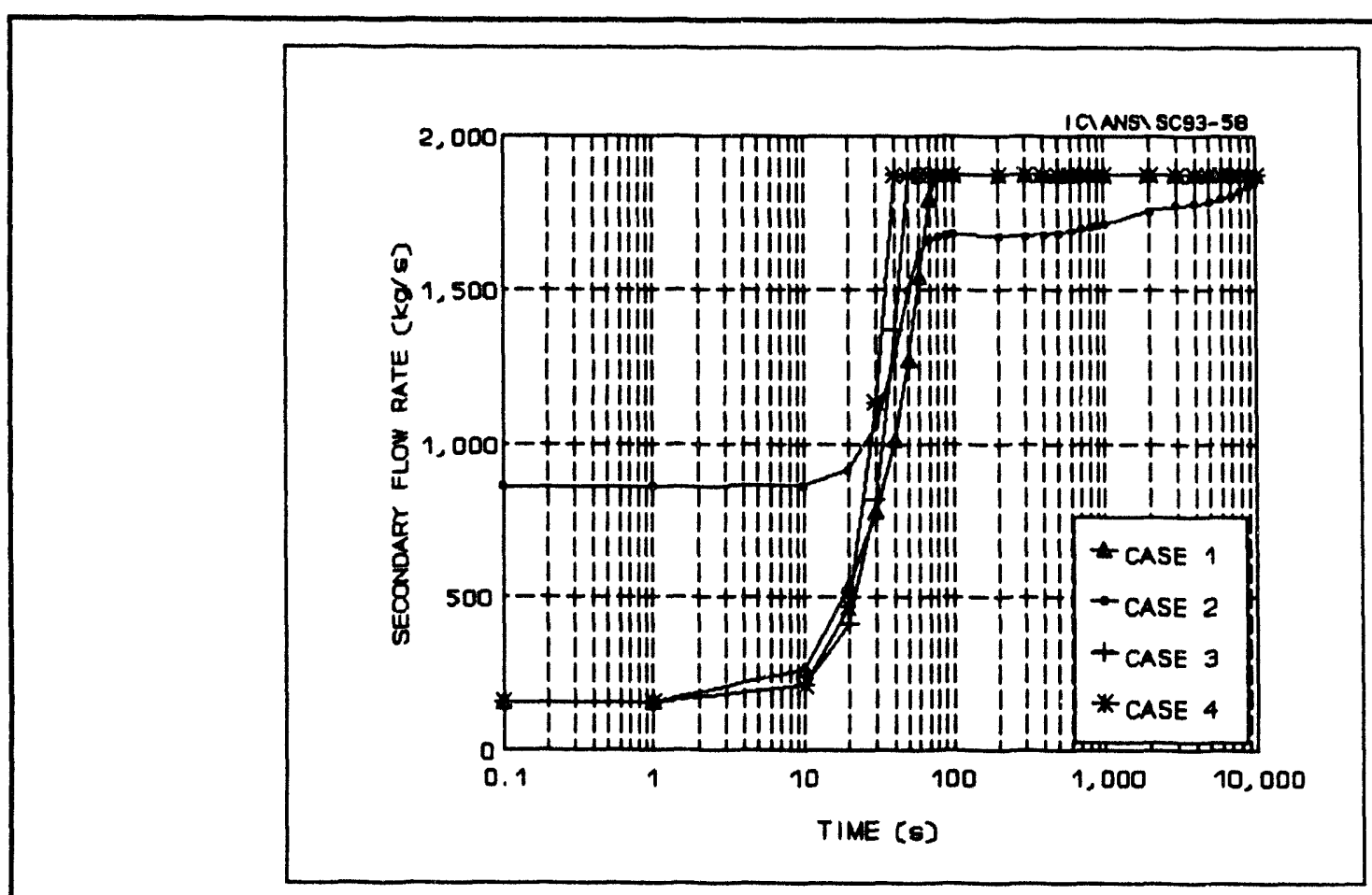

Fig. 13. Secondary flow rate for Option 3. 


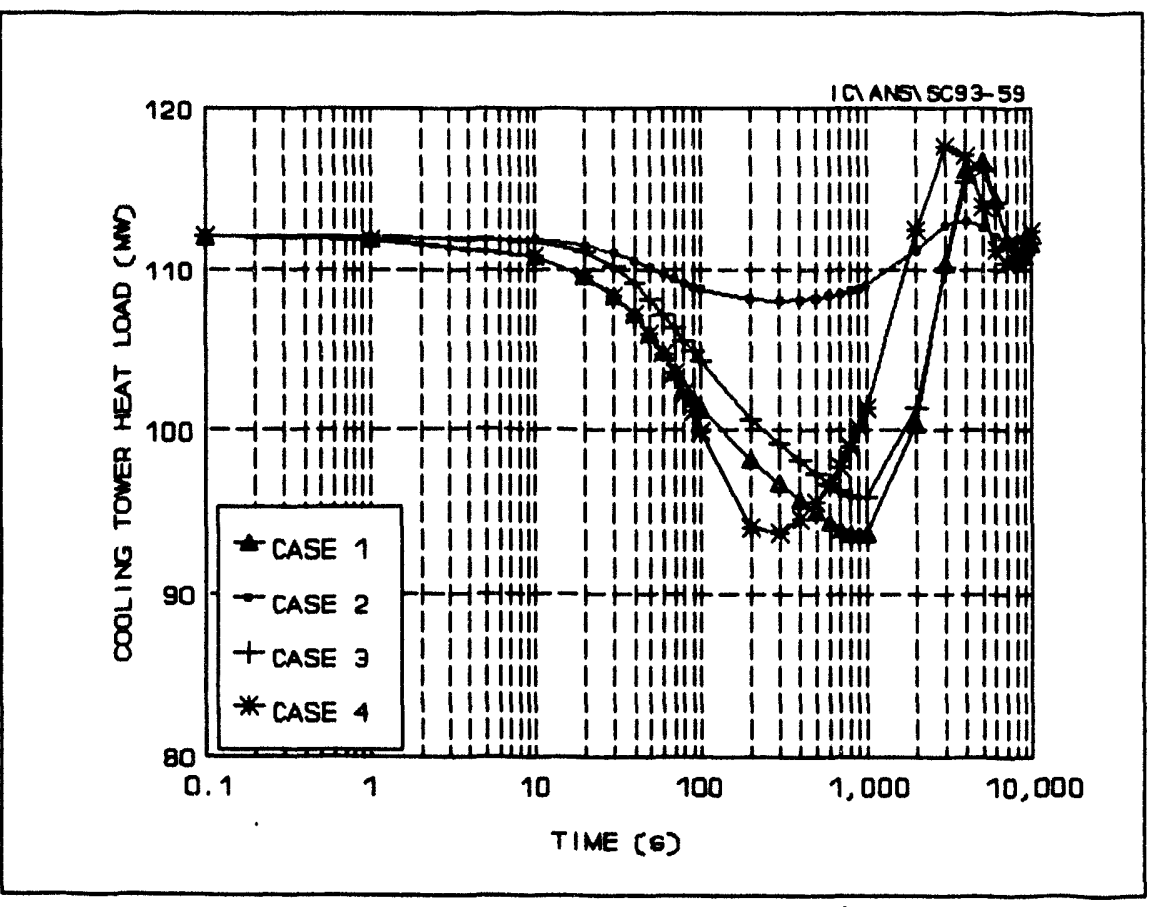

Fig. 14. Cooling tower heat load for Option 3.

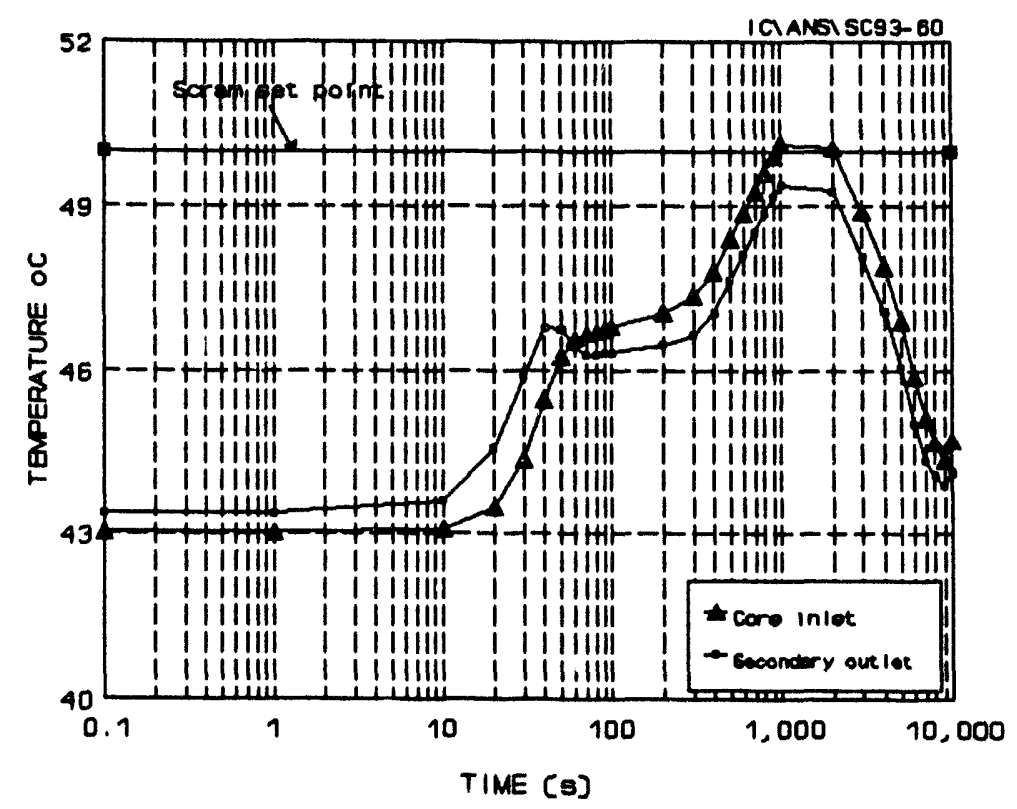

Fig. 15. Core-inlet and secondary hot-leg temperature for Option 3 following a power reduction to $40 \%$ when fan speed is not properly selected. 


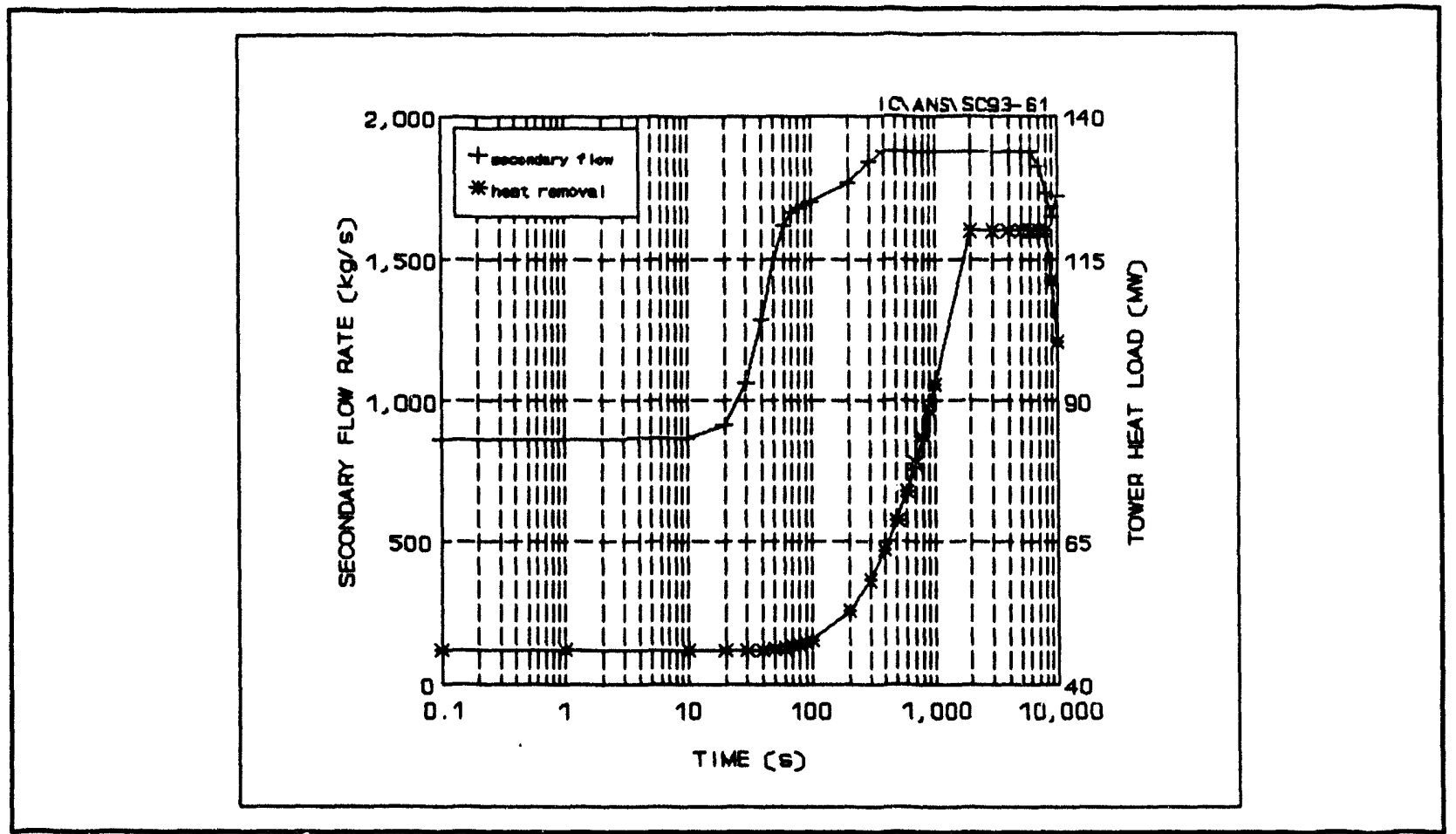

Fig. 16. Secondary flow rate and cooling tower heat load for Option 3 following a power reduction to $40 \%$ when fans speed is not properly selected. 


\section{SUMMARY AND CONCLUSIONS}

All three design options studied have inherent limitations that need to be considered for construction.

For the first option (variable-speed pumps and variable-speed fans), a requirement is to maintain a pump speed to a value that will assure flow circulation through the cooling tower. The cooling tower fan controllers will keep the off-tower temperature at $30^{\circ} \mathrm{C}$. At startup, the fans will not be running until the off-tower temperature reaches the set point $\left(30^{\circ} \mathrm{C}\right)$. This feature circulates hot water that may be used to heat the basin during startup in cold season. Option 1 is the current baseline design, and it is still the recommended option.

In the second option (single-speed pumps and variable-speed fans) an important limitation is that the core-inlet temperature is not directly controllable. This limitation does not pose a difficulty as long as the proper measures are taken to keep the secondary pumps running at full speed and the cooling tower fans are operated to keep the off-tower temperature $530^{\circ} \mathrm{C}$. This method is the most economical because it includes only one control device and is easier to design and to manipulate. The cost is reduced by eliminating the variable-speed pump controllers used in Option 1 . If there is no lower limit on the core-inlet temperature, then the cost may be reduced more, and the design basis of the controllable fans may be simplified by changing from variable-speed fans to manual discrete (or step) speed fans that allow the operator to decide on the off-tower temperature limit.

For the third option (variable-speed pumps controlling the secondary hot leg at $\sim 45^{\circ} \mathrm{C}$ and variable-speed fans), it is necessary either to couple the core-inlet temperature signal with the secundary pump speed controller or to increase the minimum secondary flow speed and the minimum cooling tower fan speed set points to a limit that can avold primary core-inlet temperature overshoot or undesirable increases. By increasing secondary flow response to core-inlet temperature escalation first and starting the cooling tower fans at high speed, enough heat will be removed from the primary by the secondary sides to avoid temperature overshoot in both sides of the reactor cooling circuit. 
ONRL/TM-12649

Internal Distribution

1. J. L. Anderson

2. B. R. Appleton

3. R. E. Battle

4-8. J. H. Campbell

9. N. C. J. Chen

10. D. Fry

11. R. M. Harrington

12-15. R. L. Johnson

16. J. A. March-Leuba

17. B. S. Maxon

18. G. R. McNuṭt

19. D. L. Moses

20. F. J. Peretz
21. C. C. Queen

22. D. L. Selby

23. J. P. Schubert

24. M. Siman-Tov

25. M. W. Wendel

26. C. D. West

27. G. L. Yoder

28. ORNL Patent Office

29-30. Central Research Library

31. Y-12 Technical Library,

Document Reference Section

32-33. Laboratory Records

34. Laboratory Records (RC)

\section{External Distribution}

35. R. Awan, U.S. Department of Energy, NE-473, Washington, DC 20585

36. K. K. Conway, Laboratory Facilities Branch, U.S. Department of Energy, Oak Ridge Operations Office, CE-523, P.O. Box 2001, Oak Ridge, TN 37831-2001

37. R. A. Hunter, Director, Office of Facilities, Fuel Cycle, and Test Programs, Nuclear Energy Division, U.S. Department of Energy, NE-47, Washington, DC 20585

38. T. L. Kerlin, University of Tennessee, College of Engineering 315 Paxqua Engineering Building, Knoxville, TN 37996-2300

39. J. P. Mulkey, U.S. Department of Energy, NE-473, Washington, DC 20585

40. W. T. Oosterhuis, Materials Sciences Division, Office of Energy Research, U.S. Department of Energy, ER-132, Washington, DC 20585

41. I. Thomas, Director, Materials Sciences Division, Office of Energy Research, U.S. Department of Energy, ER-13, Washington, DC 20585

42-43. U. S. Department of Energy, ANS Project Office, Oak Ridge Operations Office, FEDC, MS8218, P.O. Box 2009, Oak Ridge, TN 37831-8218

44. Office of Assistant Manager for Energy Research and Development, U.S. Department of Energy, Oak Ridge Operations Office, P.O. Box 2001, Oak Ridge, TN 37831-2001

45-46. Office of Scientific and Technical Information, P.O. Box 62, Oak Ridge, TN 37831 

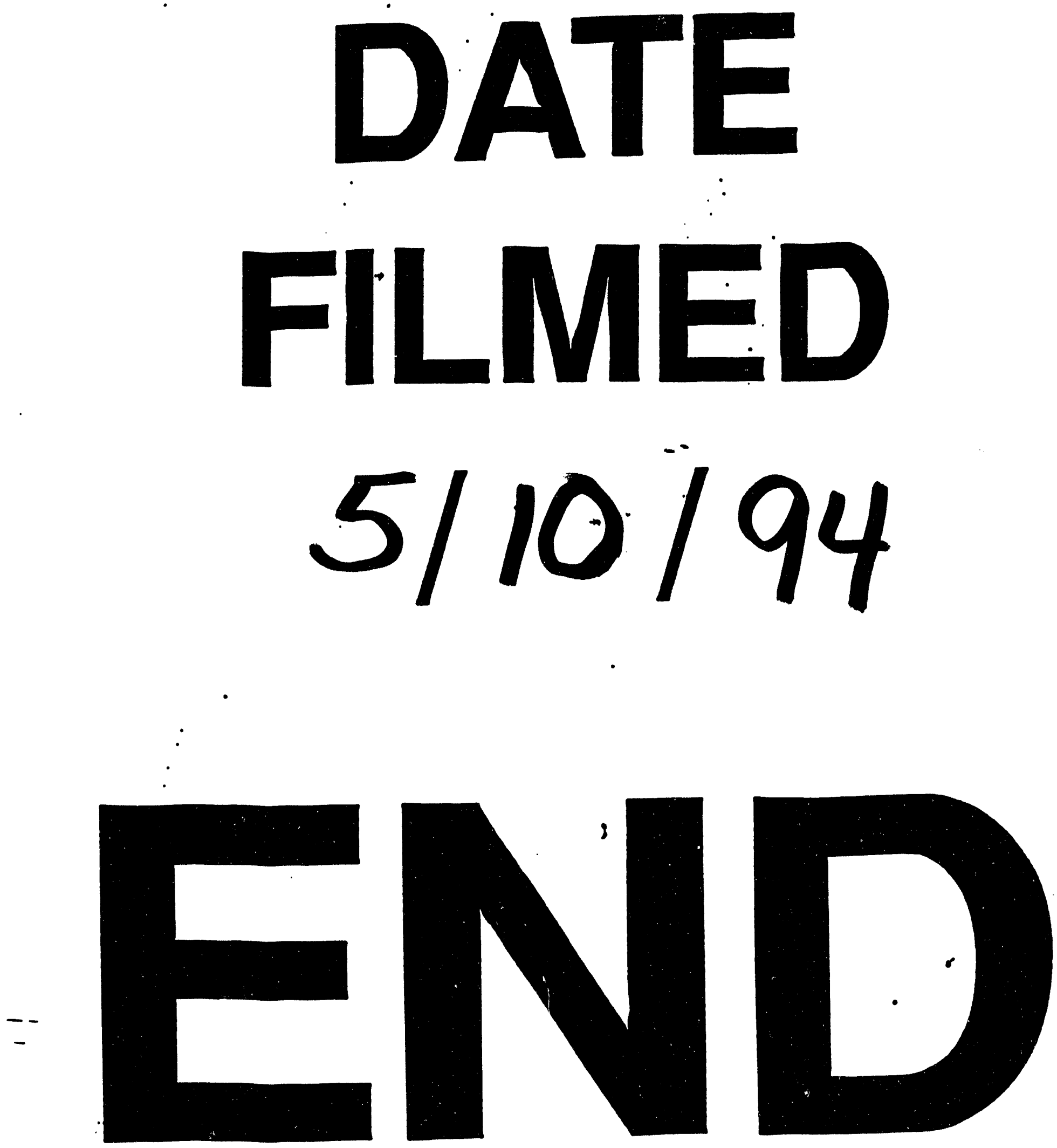